The International Journal of Banking and Finance, Volume 10 (2), 2013: pages 94-133

\title{
DETERMINING THE ROLE OF DEBT IN THE ECONOMY AND A NEW APPROACH FOR SOLVING SOVEREIGN DEBT CRISES
}

\author{
Munawar Iqbal
}

King Abdul Aziz University, Saudi Arabia

\begin{abstract}
This paper aims to begin a dialogue on how to seek a longer term solution to the sovereign debt problems in general and those of EU in particular. Although the history of debt crises is quite old, none of the several solutions proposed and tried in the past have been successful to curb recurring debt crisis. This issue has assumed critical importance as the Eurozone debt crisis, which followed after the 2007-09 global financial crisis. Several governments have been outvoted in Europe due to this crisis and the cohesion of Eurozone is at stake. A rethinking on debt creation and its macroeconomic effects are being seriously studied. It seems that traditional options available to policy makers have lost much of their luster. It is high time that unconventional measures may have to be offered for consideration to provide longer term solution. This paper is a brief on the Islamic approach to the role of debt, and has potential to limit debt creation in the long term. We present some basic tenets of that approach referring in particular to the current dev eloped nation sovereign debt crisis.
\end{abstract}

Keywords: Sovereign debt, Islamic finance, Debt overhang, Asset backing, Leveraging and growth.

JEL Classification: $\mathrm{H} 63$

"When national debts have once been accumulated to a certain degree, there is scarce, I believe, a single instance of their having been fairly and completely paid." Adam Smith (1776).

\section{Introduction}

Our understanding of Islamic rulings about debt inspires us to suggest that those rulings could be of immense help in determining the proper role of debt in the economy. This paper makes an effort to explain that approach about the role of debt in wealth creation 
and the appropriate limits to debt usage. Analyzing instances taken from the ongoing Eurozone economic crisis (2011-todate), we endeavour to derive some principles from Islamic teachings on financial management that can help to solve the problems created from excessive debt.

The decision to take debt has historically been viewed differently in different cultures. Perceptions about the extent of benefits and harms from debt have also varied in various economic situations. Over the last fifty years, debt-taking has been on the rise. There is credible literature in the web sites of several scholars with substantive data on how bad the debt burden had become under the no-risk-shared interest-based debtgiving. A recent book (Still, 2011) provides extensive data on sovereign debt, so we do not provide the easily available statistics from this and other sources freely available (IMF, World Bank, and BIS web sites).

The financial crisis that started in 2008 is the hottest political economy topic being avidly followed by human societies around the World even after five years since the onset of that crisis. Various policy measures have been suggested, of which some have been implemented. Politician and economists alike are trying their best to suggest ways to control or minimize its adverse effects on economic and social well-being of peoples in several economies. Several reasons for the crisis have been presented by analysts as well as policy makers. These reasons have been discussed in the economics literature (The Financial Times, 2013). The debate has given rise to many controversies both in economic theory and policy circles. While conservative economists hailed a return to stringency, interventionists are calling for less belt-tightening extolling Keynesian solutions, which would make debt crisis even worse.

All of these controversies hover around the role of debt in the economy, especially in the public sector. Taking debt has always been a controversial issue. In this paper, we intend to explore a novel approach, no doubt, a third approach as a longer term solution to debt overhang suggesting some unconventional measures in the public policy arena. Since debt is an issue that concerns everyone, Shakespeare's famous advice is: “... neither a borrower nor a lender be.", a wise statement that modern societies cannot live by unless economic entities are weaned off from their dependence on debt. 
Many economists took a tolerant view, commending the advantages of debt and dismissing its well known macroeconomic disadvantages. Simple minded individuals, sharp corporate managers, and vote-hungry, often corrupt politicians, went on a borrowing binge. Due to the easy-money approach of suppliers and demanders of debt, international debt market crossed $\$ 100$ trillion mark in 2011 of which more than 50 per cent is sovereign debt. That means the sovereign debt of all countries is about 75 per cent of worlds' gross domestic product (GDP), whereas the governments' revenue is a mere 31 per cent of GDP (Ariff, 2012). Undoubtedly such high levels of debt are unsustainable. The situation in the private sector is also quite serious as we will explain in subsequent sections. The interaction between various sectors of the economy has made the picture much gloomier.

There is an influential school of thought that considers that leveraging as an useful way of increasing wealth. Accounting theory demonstrates that the return on equity is increased (leveraged) by the addition of debt. If a firm's ROE (return on shareholders' fund) is say 10 per cent with 100 per cent equity, the ROE with 50 per cent debt and 50 per cent equity would be about 20 per cent. Furthermore, because interest cost is exempted from tax, debt is the cheapest source of capital. It is claimed that debt can open up many opportunities for individuals while corporations and governments could fulfill funding needs or capture opportunities that their capital cannot afford. National income can be increased by putting more idle resources into use by leveraging the productive force of equity capital with some amount of borrowing.

Another school has long since advocated that debt (except in very exceptional cases) leads to many long term problems such as heavy debt servicing burden, debt overhang, debt-addiction, higher interest rates as risk of more debt makes further debt more risky. All these ills could likely crowd out good investments and create false expectations leading to speculation. Borrowing could also make firms and governments become financially weak if there is debt beyond an optimal level (Miller and Modigliani, 1961; Warner, 1977). Some even claim that economic bubbles in various sectors build up with over-liberal availability of debt (as credits supplied by fractional banking). Ultimately bubbles burst, recession occurs and cause huge loss of wealth and 
socio-political unrest as happened from the easy-credit policy of US banking during 1994-05.

Perhaps both of these are extreme views. The public debate about the Eurozone debt crisis is part of a worldwide debate on debt overhang. Global financial crisis (20079), the worst since the Great Depression of the 1929-33, is having a curtailing impact on the economic and social thinking about the role of debt and the risk of debt. The 201113 Eurozone debt crisis raised a number of questions about the tolerant view on debt of the interventionist. Many of those who took liberal stands with respect to debt are being forced to reconsider their opinions. It is generally agreed that the root cause of the EU debt crisis is 'excessive' debt, that is, debt overhang. Many elected governments have fallen in Europe partly due to crisis-driven election platforms on the issue of public debt problem and the adverse consequences from continuing with proposed policies of governments in power. The very existence of EU as a single currency region since 1992 is increasingly at stake. We believe that the world is ready, per force, to consider alternative solution under the Islamic view on debt.

In section 2 we discuss the role of debt and its limits for households, corporate and public sectors. In section 3 we explain the anatomy of a financial and economic crisis based on historical experiences. Section 4 gives a brief account of the rescue operations being undertaken by governments and central banking authorities. We present components of a non-conventional approach for solving the problem in section 5. Six principles for handling debt based on Islamic teachings are explained. In the last section we present conclusions of this paper in the form of eight axioms on debt and economic stability that emerge from the analysis in this paper, based on Islamic economics and finance literature.

\section{Role of Debt and its Limits}

In this section, a brief survey of debt as a problem is explained. Living within one's means is a golden principle that applies to individuals, corporations and governments alike, the three actors in the economy. This does not mean that there is absolutely no role for debt in economic matters. Nevertheless, it must be realized that debt is a double edged sword. There are circumstances when debts may become unavoidable. 
Furthermore, if used in moderation and 'wisely', it may have some benefits. However, except in exceptional cases of disability, the general rule is that if one expects a future stream of income (or assets), the receipt of which is fairly assured, that will enable one to pay off debt, hence incurring debts (leveraging) can be a useful short run technique to improve one's economic conditions. Optimal leverage hypothesis advocated in financial economics signifies the same rule. This rule applies to individuals, corporations and governments alike. While the main focus of this paper is public debt, some comments on consumer and corporate debts may be helpful because of the inter-linkages between these and public debt.

\subsection{Consumer Debt}

One of the reasons that policy makers failed to predict the seriousness of the present debt crisis (and for that matter all previous ones) is under-realization of the interactions between private and sovereign debt. Adair Turner, former Chairman of the United Kingdom Financial Services Authority spoke about this incredible lack of foresight. Experts failed to understand that high — and growing — debt burdens, especially in the private sector, endangered economic stability. Policymakers thought private debt had no impact on macroeconomics. "That assumption was dangerous, because debt contracts have important implications for economic stability. They are often created in excess, because in the upswing of economic cycles, risky loans look risk-free. And, once created, they introduce the rigidities of default and bankruptcy processes, with their potential for fire sales and business disruptions... Private leverage levels, as much as the public-debt burden, must therefore be treated as crucial economic variables."1

For individuals, economic justification for the rule that leveraging can improve one's economic conditions was provided by consumer behaviour theories propounded by Milton Friedman, in his Permanent Income Hypothesis (1957) and Modigliani and Blumberg's Life Cycle Hypothesis (1954). According to these theories of consumer behaviour, consumers can borrow money to finance expenditures particularly housing

\footnotetext{
${ }^{1}$ Quoted in Kling Michael (2013).
} 
and schooling earlier in their lives and pay back that debt in later years which are usually higher-earning periods. Assets built through higher earnings and leveraging in early working age allow a smoother consumption pattern, including in the post retirement periods. This can be useful only if the rule stated above is strictly adhered to. Unfortunately, due to liberal consumer loans policies and practices, especially the emergence of 'plastic money', the amount of debt outstanding versus the consumer's disposable income has risen to unsustainable levels in most advanced countries. Household debt in the United Kingdom rose from less than 15 percent of GDP in 1960 to more than 90 percent in 2008. In the United States, total private credit increased from about 70 percent of GDP to well over 200 percent in $2008 .^{2}$

Table 1: Ratio of Household Debt to Disposable Income in EU 17

\begin{tabular}{|c|c|}
\hline Year & Debt/GDP Ratio \\
\hline 2000 & 0.749 \\
\hline 2001 & 0.751 \\
\hline 2002 & 0.771 \\
\hline 2003 & 0.796 \\
\hline 2004 & 0.830 \\
\hline 2005 & 0.876 \\
\hline 2006 & 0.915 \\
\hline 2007 & 0.940 \\
\hline 2008 & 0.950 \\
\hline 2009 & 0.976 \\
\hline 2010 & 0.998 \\
\hline $\mathbf{2 0 1 1}$ & $\mathbf{1 . 0 0 0}$ \\
\hline
\end{tabular}

Source: Eurostat; http://ec.europa.eu/eurostat.

The number of households who carry consumption debt is quite high in almost all advanced countries including those in the EU, and hence the amount of debt. When would consumer debt be considered too high? A number of parameters are used to determine that. The most commonly used measure is the debt/disposable income ratio,

\footnotetext{
${ }^{2}$ Kling, ibid.
} 
the so-called Consumer Leverage Ratio. It is generally believed that a ratio of more than 0.6 indicates household debt to be high. Statistics presented in Table 1 show that Euro zone countries have crossed that limit long since and the ratio reached 1.0 in 2011. In the UK also, it is close to $1.0 .^{3}$ In the US, statistics released by the Bureau of Economic Analysis and the Federal Reserve show that the Consumer Leverage Ratio has been between 1.2 to 1.3 throughout the $2005-2009$ period.

Another indicator used to determine whether or not consumer loans are within safe limit is the debt servicing as a percentage of gross household income. In this respect, a study ${ }^{4}$ on New Zealand household debt defines 'vulnerable households' as those having a debt servicing obligations exceeding 30 per cent of their gross income. The same study found that the percentage of vulnerable household in 2008 was more than 16 per cent. That means one in every six households was in the vulnerable household category. In the UK, a report by BIS $^{5}$ published in June 2011 showed that 12 per cent of households may be defined as being in financial difficulties and another 11 per cent (total of 33 per cent) of households are considered to be at risk of financial difficulties. Another report ${ }^{6}$ on the UK household debt states that 6.2 million households are financially vulnerable. In the US, the household Financial Obligations Ratio (FOR) peaked at 17.7 per cent of disposable income in 2007. Thereafter, it has had a downward trend but as at 2012, it was around 14.0 per cent. ${ }^{7}$

Easy access to credit may have some benefits, but once one lifts the guard, debt sneaks in like a snake and quickly grows into a dangerous serpent. The worst part of it is that most, if not all, debt is unnecessary and could be avoided. Hardly anyone will question the undesirability of what is known as gambling debt. Yet the volume of such debt runs into billions of dollars. The average (gambling) debt in US is between $\$ 55,000$ and $\$ 90,000$ and is increasing. ${ }^{8}$ We know gambling is an addiction but easy access to debt plays an important role in facilitating and continuing in that addiction. It would be no exaggeration to state that debt itself is addictive.

\footnotetext{
${ }^{3}$ Creditaction.com, Debt Statistics released in April 2013.

${ }^{4}$ Henderson Katherine and Grant M. Scobie (2009).

${ }^{5}$ Department of Business Information and Skills, UK (2011)

${ }^{6}$ Financial Inclusion Centre (2011).

${ }^{7}$ Data released by the Federal Reserve Board, March 2013.

${ }^{8}$ Debt.org
} 
Let us consider a supposedly more benign type of debt, the credit card debt, where one can charge one's dinners and holidays to credit cards, not to speak of furnitures, television and almost every consumer durable. According to Nelson Report, which reports credit card data for US consumers on a regular basis, the volume of credit card purchases in 2011 amounted to \$2,050 trillion. ${ }^{9}$ Benjamin Franklin, who earned the title of The First American for his foundational role in defining the American ethos, once said: "Rather go to bed without dinner than to rise in debt." Now as one famous American columnist Earl Wilson said: "modern man drives a mortgaged car over a bond-financed highway on credit-card gas". Among the 185 million card-holding U.S. consumers, the average person carries three bankissued credit cards, four retail credit cards and one debit card, according to CardWeb.com. According to a survey by the American Bankers Association and Dove Consulting conducted in 2005-06, plastic payments accounted for 53 per cent of consumer purchases, compared to 43 per cent in 1999. The average credit card debt per card holder is estimated to be more than $\$ 6,500$. Use of plastic money is not bad per se. The problem is that access to easy money, does not allow people to make their calculations right. Some circles claim that with credit card, one can track one's expenses more easily. That may be true. But what it makes easy to track is one's past expenses. At the moment of making the expense, one hardly thinks whether she can afford that $\$ 500$ purchase or not. It is like putting one's car on 'cruise control', with the brakes not working. Would that not put one to a big risk of a crash, a debt overhang crisis?

\subsection{Corporate Debt}

In the area of corporate debt, the natural point to begin discussion is the famous Modigliani-Miller Theorem (MMT). This theorem states that a firm's value, under no interest deduction for tax, is independent of how it is financed, i.e., leveraging does not affect its value. It only determines the distribution of expected cash flow streams from operations among creditors and owners. The MMT paradigm has been extensively studied. Even though, the results are not conclusive, the debt proliferators

\footnotetext{
${ }^{9}$ Nelson Report (2012).
} 
have conveniently ignored its main message. Without any conclusive evidence, they have relied on some partial and conflicting results to justify borrowing as heavily as their credit rating would allow.

The school of thought that advocates leveraging as a mean of increasing wealth often advocates using other peoples' money to prosper. This school believes that it is the easiest way to get rich. That is attractive in theory, but when it comes to practice, it is quite different. When someone takes a loan to start a new business instead of equity, he alone faces the high risk if the business fails. That risk is quite substantial. As shown in Table 2, in the US twenty five per cent of new businesses (average of business and industrial sector) fail within the first year and fifty per cent in the first four years.

Table 2: Failure Rates of New Businesses in the United States

\begin{tabular}{|c|c|}
\hline Year & Percent Failed \\
\hline 1 & 25 \\
\hline 2 & 36 \\
\hline 3 & 44 \\
\hline 4 & 50 \\
\hline 5 & 55 \\
\hline
\end{tabular}

Source: Statisticbrain.com: Verified by University of Tennessee Research.

It is pertinent to note here, that an Islamic debt-like instrument, called sukuk, can overcome this problem. It enables risk-sharing and gives new entrepreneurs better terms for investing. By barring interest-on-interest practice, it prevents borrowing beyond capacity to pay back as the partners become more vigilant due to their stakes involved and are also obliged to participate in loss (Ariff et. al. 2012).

Another factor is that leveraging creates a feeling of 'deceptive richness' among investors which creates false booms. On the business cycle up-turn, rising leverage gives a false impression of increasing wealth. This is what subprime mortgage lending did to Americans when actually they were suffering from stagnant or falling real wages. In the downturn that followed, overleveraged businesses and consumers reduce investments and consumption in order to pay off debts. Japan's lost decades after 1990 are a stark example of such behaviour. 
After the financial crisis of 2008-09, there have been influential voices questioning the usefulness, or at least the level of, corporate leveraging that one observes. It would be useful to quote here some statements from an ongoing dialogue that started from the discussions at the Brookings Panel on Economic Activity 2010. At that forum, Alan Greenspan, the famous long-serving former Chairman of US Federal Reserve (1987-06), presented a paper "The Crisis". He made a number of reform proposals in that paper. One of those was raising capital requirements and hence reducing leverage. However, he suggested that there are limits to how much we can do so. He was of the opinion that if businesses reduce leverage too much, financial intermediaries will not be sufficiently profitable to remain viable. In other words, he (a) believes that in principle reducing leverage ratio is good economics but (b) considers the scope of such reduction in practice to be limited. ${ }^{10}$ His proposals have generated a lot of debate. In that debate, a large majority agrees on reducing leverage. Furthermore, there are influential voices which questioned Greenspan's reservation on the limits to such reduction.

One such voice is that of Harvard economist Greg Mankiw whose position is worth quoting. He says, "Indeed, I think it is possible to imagine a bank with almost no leverage at all. Suppose we were to require banks to hold 100 per cent reserves against demand deposits. And suppose that all bank loans had to be financed 100 per cent with bank capital. A bank would, in essence, be a marriage of a super-safe money market mutual fund with an unleveraged finance company. (This system is, I believe, similar to what is sometimes called "narrow banking"). It seems to me that a banking system operating under such strict regulations could well perform the crucial economic function of financial intermediation. No leverage would be required."

Another recent study ${ }^{11}$ states: "the fact that banks choose high leverage does not imply that this is socially optimal, and, except for government subsidies and viewed from an ex ante perspective, high leverage may not even be privately optimal for

\footnotetext{
${ }^{10}$ That is practicing bad economics for so long has made getting out of it very difficult.

${ }_{11}$ Anat R. Admati et al., "Fallacies, Irrelevant Facts, and Myths in the Discussion of Capital Regulation: Why Bank Equity is Not Expensive", Graduate School of Business, Stanford University, Manuscript, March 2011.
} 
banks". ${ }^{12}$ These views are, and will continue to spur a lot of debate. However, abstracting from the value of a such a firm idea and considering the interest of the economy in general, we believe that if we factor in the above-mentioned risk factors (and not all risk in the contemporary world have been mentioned), they will far outweigh any benefit that could be gained by leveraging not securely linked to the real sector in an economy. If and when leveraging is to be considered, it must be considered keeping in view 'sustainable' growth in the real economy.

\subsection{Public Debt}

Economic justification for governments to borrow comes from the purported growth-boosting potential of debt. The Keynes's theory of aggregate demand is behind that supposition. Lord Maynard Keynes, perhaps the most influential economist in the history of economic thoughts, had suggested in the Theory of Aggregate Demand that governments can use fiscal policies (budget deficits) as well as monetary policies (by lowering the interest rates) during depressions to boost aggregate consumer and investment demands to grow, which in turn increase employment and national income. Other economists drew attention to many loopholes in Keynes' theory but in the depth of Great Depression, his theory became popular among policy makers: government debt was not too high at that time.

In Table 3, we present data released by the Bank of International Settlement on gross government debt as a percentage of GDP for the period 1990-2013. ${ }^{13}$ In recent years, witnessing the worst depression after the Great Depression, his followers named by some economists as vulgar Keynesians have been recommending similar measures. Once again, under the burden of recession, policy makers followed many of those policies. As a result government debt increased sharply. Policy makers hoped that the conventional (but unreliable) pump priming via debt technique will help them getting out of the crisis.

However, the relationships between low rates of interests - high budgetary deficits and growth have all been questioned. According to Leigh Skene of Lombard Street

\footnotetext{
${ }^{12}$ http://gregmankiw.blogspot.com/

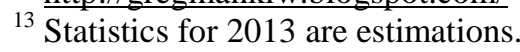


Research, ${ }^{14}$ each additional dollar of debt is associated with less and less growth. A working paper issued in September 2011 by the Bank of International Settlements ${ }^{15}$ summarizes the findings of an extensive research based on a huge dataset containing long time series/cross-sectional data as follows:

“At moderate levels, debt improves welfare and enhances growth. But high levels can be damaging. When does debt go from good to bad? We address this question using a new dataset that includes the level of government, non-financial corporate and household debt in 18 OECD countries from 1980 to 2010. Our results support the view that, beyond a certain level, debt is a drag on growth. For government debt, the threshold is around $85 \%$ of GDP. The immediate implication is that countries with high debt must act quickly and decisively to address their fiscal problems. The longer-term lesson is that, to build the fiscal buffer required to address extraordinary events, governments should keep debt well below the estimated thresholds. Our examination of other types of debt yields similar conclusions. When corporate debt goes beyond $90 \%$ of GDP, it becomes a drag on growth. And for household debt, we report a threshold around 85\% of GDP."

There were signs from early 2007 onwards that economies were reaching the limit of their ability to absorb more borrowing that could not yield positive effects on growth. Debt-addition prevented them to return to economic fundamentals. In addition, as reported later in the paper, there is evidence of positive correlation between corruption and higher public debts. In brief, it was more for political rather than economic reasons that the debt pile up went for so long. It seems that many rich countries exhausted the growth-boosting potential of debt. With ageing populations and shrinking workforces, their economies may only grow more slowly than in the past. They may have borrowed from the future, using debt to enjoy a standard of living that is unsustainable presently. Greece provides a stark example. Standard \& Poor's estimates that her GDP will not regain its 2008 level until $2017 .^{16}$

\footnotetext{
${ }^{14}$ Leigh Skene (2012).

${ }^{15}$ Cecchetti, G. Stephen et.al. (2011).

16 ibid.
} 
Table 3: Gross Government Debt as Percentage of GDP

\begin{tabular}{|c|c|c|c|c|c|c|c|c|c|c|c|}
\hline Year & $\begin{array}{l}\text { Advanced } \\
\text { Economies }\end{array}$ & US & UK & Germany & France & Italy & Spain & Greece & \begin{tabular}{|l|} 
Portugal \\
\end{tabular} & Ireland & Japan \\
\hline 1990 & 58.90 & 63.14 & 32.31 & 37.02 & 38.57 & 97.17 & 47.68 & 74.71 & 60.52 & 108.78 & 63.89 \\
\hline 1991 & 61.67 & 67.88 & 32.80 & 37.69 & 39.46 & 99.94 & 49.55 & 77.15 & 63.10 & \begin{tabular}{|l|}
110.38 \\
\end{tabular} & 63.21 \\
\hline 1992 & 65.49 & 70.27 & 38.97 & 40.81 & 43.85 & 106.24 & 52.08 & 82.42 & 56.56 & 106.89 & 67.58 \\
\hline 1993 & 70.45 & 71.88 & 48.73 & 46.11 & 50.80 & 115.55 & 65.54 & 103.37 & 61.40 & 109.89 & 73.86 \\
\hline 1994 & 71.52 & 71.08 & 46.84 & 46.48 & 60.08 & 120.35 & 64.31 & 101.31 & 64.51 & 103.52 & 78.97 \\
\hline 1995 & 73.99 & 70.67 & 51.58 & 55.68 & 62.60 & 122.03 & 69.28 & 102.03 & 66.77 & 95.89 & 86.24 \\
\hline 1996 & 75.54 & 69.90 & 51.20 & 58.82 & 66.37 & 128.13 & 75.98 & 104.07 & 66.55 & 85.84 & 93.81 \\
\hline 1997 & 75.14 & 67.43 & 52.02 & 60.36 & 68.93 & 129.62 & 75.00 & 100.92 & 65.32 & 75.18 & 100.45 \\
\hline 1998 & 75.48 & 64.21 & 52.53 & 62.33 & 70.40 & 131.67 & 75.33 & 98.57 & 63.27 & 62.60 & 113.17 \\
\hline 1999 & 73.93 & 60.50 & 47.39 & 61.83 & 66.86 & 125.50 & \begin{tabular}{|l|}
69.39 \\
\end{tabular} & 102.42 & 60.51 & \begin{tabular}{|l|}
51.69 \\
\end{tabular} & 127.04 \\
\hline 2000 & 71.19 & 54.52 & 45.16 & 60.85 & 65.73 & 120.97 & 66.51 & 116.35 & 60.23 & 39.96 & 135.38 \\
\hline 2001 & 71.36 & 54.45 & 40.40 & 60.10 & 64.30 & 120.12 & 61.89 & 119.16 & 61.68 & 37.44 & 143.67 \\
\hline 2002 & 73.67 & 56.82 & 40.84 & 62.50 & 67.54 & 118.74 & 60.32 & 118.64 & 65.04 & 35.72 & 152.28 \\
\hline 2003 & 75.81 & 60.16 & 41.50 & 65.87 & 71.74 & 116.34 & 55.34 & 113.34 & 66.76 & 34.51 & 157.98 \\
\hline 2004 & 77.53 & 61.25 & 43.79 & 69.26 & 74.11 & 116.66 & 53.34 & 115.80 & 69.29 & 33.14 & 165.54 \\
\hline 2005 & 79.22 & 61.50 & $\underline{46.39}$ & 71.78 & 76.04 & 119.44 & \begin{tabular}{|l|}
50.74 \\
\end{tabular} & 113.35 & 72.84 & 32.94 & 175.27 \\
\hline 2006 & 77.48 & 60.93 & 46.04 & 69.83 & 71.21 & 116.87 & 46.20 & 116.91 & 77.61 & 29.19 & 172.15 \\
\hline 2007 & 76.27 & 62.12 & 47.17 & 65.57 & 72.96 & 112.12 & 42.35 & 115.04 & 75.42 & 28.65 & 167.05 \\
\hline 2008 & 83.42 & 71.40 & 57.43 & 69.74 & 79.27 & 114.69 & \begin{tabular}{|l|}
47.70 \\
\end{tabular} & 118.07 & 80.69 & 49.59 & 174.10 \\
\hline 2009 & 96.37 & 85.03 & 72.45 & 77.44 & 90.82 & 127.10 & 62.86 & 133.47 & 93.27 & 71.11 & 194.05 \\
\hline 2010 & 103.33 & 94.17 & 82.19 & 87.06 & 95.18 & 126.12 & 67.06 & 149.07 & \begin{tabular}{|l|}
103.58 \\
\end{tabular} & 98.46 & 199.97 \\
\hline 2011 & 107.85 & 97.60 & 89.95 & 86.88 & 98.62 & 127.74 & 74.13 & 165.10 & 111.94 & 112.57 & 211.73 \\
\hline 2012 & \begin{tabular}{|l|}
112.67 \\
\end{tabular} & 103.64 & 97.20 & 87.34 & 102.35 & 128.11 & 77.23 & 181.24 & 121.93 & 118.82 & 219.05 \\
\hline 2013 & 116.19 & 108.45 & 102.28 & 86.44 & 104.05 & 126.59 & 78.97 & 183.89 & 123.68 & 122.42 & 226.82 \\
\hline
\end{tabular}

Source: Bank of International Settlements, Annual Report, 2012.

The prevailing uncertainty in the markets created an opportunity for the gamblers (speculators) to fish in troubled waters. The derivatives market ballooned and crossed in 2012 the quadrillion dollars mark. That is 20 times the World economy. According to many analysts the global financial crisis of 2007-09 was caused in part by the proliferation of non-performing derivative products tied to US home loans that triggered hundreds of billions of dollars in write downs (Ariff et al., 2012). Bankruptcy of Lehman Brothers Holdings Inc., in September of 2008, the largest ever 
in history, was only the tip of the iceberg. Derivatives caused havoc all around the world. The worst part of the story is that the bulk of the OTC derivatives market is largely un-regulated.

\section{Making of Financial Crises}

Why are financial crises often associated with debt overhang? Many researchers believe that interest-based borrowing, especially speculative borrowing (apparently hedged by derivatives) and budgetary deficits are among the root causes of crises, so is the case of the EU Debt Crisis. The history of financial and economic crises is centuries old (Kindleberger, 2005). However, the intensity of these crises has been increasing over time primarily due to derivatives, debt overhang and the breakdown of Bretton Woods rules.

In the economic literature, causes of past crises have been studied in great detail. Reinhart and Rogoff (2009) ${ }^{17}$ provide an excellent survey going back eight centuries. Though there are some unique features of every financial crisis and within each special aspects for each country affected, however, there are some characteristics that are common. In the opinion of the present author, three factors are most prominent in all crises occurring in the last 50 years. These are: (i) reliance rather over-reliance on interest-based borrowing; (ii) excessive public sector involvement in the economy; and (iii) speculation in stock, foreign exchange and commodity markets. The problems are compounded because these three elements have strong inter-linkages among them magnified by the use of derivatives.

Let us review financial crisis as a case study over the 2007-todate. Immediately before the crisis the interest rates were low. Individuals increased their borrowing in the form of mortgage loans, many of those being sub-prime mortgages. Real estate prices started rising so much so that a real estate bubble built over 12 years had to burst by a 48 per cent price falls over 2007-09. Since real estate is one of the most commonly used collateral for bank loans, banks were ready to offer other types of consumer loans. Moreover, with higher real estate prices, property owners' net worth

\footnotetext{
${ }^{17}$ Reinhart, Carmen M. and Kenneth S. Rogoff (2009).
} 
also increased. That encouraged them to take higher credit card loans. The consumer leverage ratios in all advanced countries increased. This ratio in the EU increased from below 75 per cent in 2001 to 95 per cent in $2007 .{ }^{18}$ By that time it had become obvious that many countries around the globe including EU nations, the UK, Japan and the US were experiencing property bubble.

In the corporate sector, enterprises encouraged by low interest rates increased their borrowing with the result that their capital asset ratios sharply fell. Many mega banks and other financial enterprises relied on the theory of 'too big to fail' went on a borrowing binge to lend. Banks having the ability to create credit by the stroke of a pen on the famous money-multiplier formula and profiting by interest rate margins and multiple credit creation were obliging the borrowers. Low interest rates, reducing the cost of borrowing, also provided a golden opportunity to speculators. Easy money encouraged speculation in the commodity and stock markets. They were earning handsome returns, not through dividends, but mostly through short selling. That led to a phenomenal growth of the derivatives market.

Making of a bubble was quite obvious but given a rising stock market generally considered being a sign of a booming economy, the governments turned their eyes the other way. As early as June 2005, the Economist magazine warned, "the worldwide rise in house prices is the biggest bubble in history. Prepare for the economic pain when it pops."19 As in the case of earlier bubbles, the property prices started decreasing. By 2007, the property bubble had burst like an economic bomb. While the value of the properties decreased, the level of debt did not. By 2009 the ratio of household debt to disposable income in EU countries had crossed 97 per cent. The burden of repaying/defaulting on the loan depressed aggregate demand, which in turn reduced rates of growth in GDP around the World making things more difficult for governments.

IMF statistics would have us believe that the 3.6 per cent on-long-trend growth rate of the 2005 was shaved to 1.6 per cent since then. If one takes the world GDP as

\footnotetext{
${ }^{18}$ Eurostat.

19 The Economist. June 16, 2005.
} 
US\$65 trillion, the shrinkage due to the financial bubble in the world GDP has been US\$1.3 trillion times 5, that is US\$6.5 trillion over five years to 2013. Just think of the opportunity cost of debt overhang to the wealth of nations! The number of bankruptcies and bail outs increased, putting a heavy burden on tax payers, and the skilled workers whose incomes stopped through no fault of theirs. The holders of household debt, mortgage companies and commercial banks had increasing bad debts.

\section{Rescue Operations by Governments}

Fearing a collapse of the financial sector, many governments stepped in to rescue the ailing financial institutions. On October 3, 2008, the US passed the Emergency Economic Stabilization Act of 2008 authorizing the Treasury to buy risky and nonperforming debt from various lending institutions. In Europe, a mix of policy responses was undertaken at about the same time.

In the UK, the government announced a $£ 500$ billion bailout package on 8 October, 2008. The initial British plan had three pillars: (1) recapitalization through a Bank Recapitalization Fund, for $£ 50$ billion; (2) a Credit Guarantee Scheme, a government loan guarantee for new debt issued between British banks for up to $£ 250$ billion; (3) liquidity provision through short term loans made available through a Special Liquidity Scheme operated by the Bank of England, for $£ 200$ billion.

In France, a rescue plan was enshrined into law on October 16, 2008 (loi de finances rectificative pour le financement de l'économie, no. 2008-1061). It created two ad hoc institutions: the Société de Financement de l'Economie Française (SFEF), set up to raise capital on financial markets and provide liquidity to ailing financial institutions, and the Société de Prise de Pariticipation de l'Etat (SPPE), through which the government would buy equities from the French banks and thus help to recapitalize them. The government agreed to guarantee bank bonds issued by the SFEF up to $€ 360$ billion. At the same time, the SPPE would invest $€ 10.5$ billion to recapitalize French banks by January 2009.

The combination of rescue measures for the consumer and the corporate sectors, spilled into public sector. Government had to borrow from the market issuing interestbased bonds or from the Central banks and ran excessive budget deficit in an attempt 
to pump prime the economy. They hoped that the supposed positive link between budget deficit and growth in GDP will increase rates of growth, which will in turn increase tax revenues and help balancing the budget over the business cycle.

However, several empirical studies have now shown that the positive relation between high budget deficit and high growth rates is not as simple as previously believed. $^{20}$ Based on empirical evidence, the best that can be said if the initial public debt levels had been low with low budget deficits, governments would have been successful in pump priming the economy. However, that is not the case in the present circumstances.

IMF Fiscal Monitor, 2013 states: "Most studies find that high debt levels (above 80-90 percent of GDP) have a negative effect on growth (some $0.15-0.20$ per cent per 10 percentage points of GDP). High debt also makes public finances more vulnerable to future shocks, because it constrains governments' ability to engage in countercyclical policies and because the larger the initial debt ratio, the bigger the increase in the primary surplus required to stabilize that ratio after an adverse shock to growth or interest rates. Indeed, when debt is high, there is a risk of falling into a bad equilibrium caused by self-fulfilling expectations. High debt is unsustainable because markets believe it is so". Table 4 presents average data for the 17 EU countries. It may be seen that the averages given are more than the reasonable threshold. As a matter of fact, in some individual countries the ratios are much higher.

As stated above, from an economic point of view budget deficits, except in very special cases and for short periods of time, are bad economics. However, the shackles of debt once on, are not easy to break out from. Strong lobbies are created as is evident in most Western countries. Political parties; Right, Left and Center, all agree on the need to reduce budget deficits in the shortest period of time. The signing of "The Fiscal Compact" on March 2, 2012 by all member states of the European Union (EU), except the Czech Republic and the United Kingdom was hailed as a landmark towards European fiscal integration. The treaty entered into force on

\footnotetext{
${ }^{20}$ For example see, Ursua, J and D. Wilson (2012) and Baum, A, C. et.al. (2012).
} 
January 1, 2013 for the 16 states which completed ratification prior to this date. For subsequent ratifiers, it will enter into force on the first day of the month following the deposit of ratification instruments. German Chancellor, Ms Merkel, main proponent of the fiscal discipline school was buoyed. She said at that time that the pact, which binds Euro Zone countries to keeping their deficits below 3pc, was "non-negotiable" and would "last forever". Later developments showed that her statement was a wishful thinking.

Table 4: Debt/GDP Ratios in Eurozone (17)

\begin{tabular}{|c|c|}
\hline Year & Debt/GDP \\
\hline 2000 & 74.91 \\
\hline 2001 & 75.14 \\
\hline 2002 & 77.12 \\
\hline 2003 & 79.60 \\
\hline 2004 & 83.01 \\
\hline 2005 & 87.60 \\
\hline 2006 & 91.54 \\
\hline 2007 & 93.99 \\
\hline 2008 & 94.96 \\
\hline 2009 & 97.56 \\
\hline 2010 & 99.76 \\
\hline 2011 & 99.36 \\
\hline
\end{tabular}

Source: Eurostat: http://ec.europa.eu/eurostat.

In 2012, French President Nicolas Sarkozy, seeking re-election went to the extent to promise that he intended to insert the "balanced budget" rule into the French constitution, subject to approval by French electorate in a referendum on the issue. Electorate did not buy that and he lost the election. François Hollande won the French Presidency on an anti-austerity platform. He pledged to pursue efforts to trim the country's budget deficit to avoid fueling the euro-zone sovereign-debt crisis. However, once his honeymoon in power ended, he had to face the tricky balance 
between appeasing the tax payers and the benefit seekers. With France's sluggish economy, the Euro Zone's second-largest after Germany, running short of growthstimulating power of its own, he was forced to seek help from the European Central Bank. He faced fierce opposition from the most influential and the richest member of the Euro Zone, Germany. However, the European Central Bank (ECB) is trying to find ways to keep France afloat.

Across the Atlantic, in the American Presidential elections of 2012, both front runners, Barack Obama and Mitt Romney, worried about the reaction of the electorate who considered budget deficit to be their top worry, tried to lure voters promising to cut the Federal deficit, though through different plans. They were forced into this by a public outcry after Standard \& Poor's downgraded the US credit rating and raised the fears that the United States may default on its obligations. If that could happen to a "currency issuer", who pockets billions of dollars annually in 'seigniorage', simply by running the printing press, the other countries are much more vulnerable.

\section{A Nonconventional Approach using Islamic Debt Principles}

In this section, the reader will find a third approach to managing debt based on sound debt-taking principles balanced in extreme situations with debt forgiveness. Debt forgiveness has been practiced repeatedly in historical times in Greece, Rome, China and in the US. We then derive the lessons as axioms for debt taking under this approach as a long term solution to the current debate on how to eliminate debt overhang to restore economies to sustainable growth path.

Balancing the budget in present situations of most advanced countries is easier said than done, under wither the classical or interventionist policies. It requires either austerity measures or tax increases both of which are politically unpopular: a third method is stealing wealth in place, which has been shown as unpalatable from the Cyprus experiment in 2013. Dissenting voices about austerity plans as a solution of the crisis are already being heard, and newly elected governments are distancing that choice and street protests against austerity plans began in many countries. Because of political expediencies rather than economic fundamentals, most governments are now thinking of other alternatives, in place of austerity. 
Several solutions to the sovereign debt crises have been recommended and tried in the past. Some of these have merits. However, by and large, these are only ad hoc adjustments; temporary pain killers rather than permanent cure. As in the case of palliative medicine, most often these temporary pain killers aggravate the disease. Dosage of pain killers is increased and in many cases the end result is terminal illness of the patient. In case of the EU debt crisis, per force, economists and politicians alike are ready to consider a non-conventional measure to handle the crisis? This author believes that Islamic teachings and principles for financial transactions can be helpful.

\subsection{Six Principles on Debt Creation and Discharge}

The best place to start any discussion on Islamic principles relating to finance is a reference to verses 278-280 of Chapter 2 of the Qur'an, Islam's guidepost. These verses state:

"O you who believe! Be afraid of God and give up what remains (due to you) from riba (usury) (from now onward), if you are (really) believers. And if you do not do it, then take a notice of war from God and His Messenger but if you repent, you shall have your capital sums. Deal not unjustly (by asking more than your capital sums), and you shall not be dealt with unjustly (by receiving less than your capital sums). And if the debtor is in a hard time (has no money), then grant him time till it is easy for him to repay, but if you remit it by way of charity, that is better for you if you did but know'.

These verses establish three important principles with respect to borrowing and lending which we discuss briefly.

1. The Principle of 'Principals'

The first principle specifies that the creditor must get his principal back (except in exceptional circumstances discussed below). Justice demands that is to be done. If the principal emerged from a loan contract, the lender did him a favour (expecting a reward only from God) and if it emerged from a sales contract he earned a profit once but thereafter his money has the same status as that of a lender. 
There are a number of Islamic texts that enshrine this principal. The most important of these is the following Qur'anic verse:

"If you repent, you are entitled to your principal. Deal not unjustly nor shall you be dealt with unjustly". [2: 279]

The principle of principals is also established from the following Hadith (tradition):

"Anything given for benefitting from its usufruct is to be returned, a she-camel given temporarily for milking must be given back, a debt must be discharged, and one who stands surety is responsible to honor it". [Sunan Abu Dawood: 296/3.]

There are deposit insurance schemes in many advanced countries. However, as pointed out by Askari et al. (2012), "while deposit insurance can deter runs on solvent banks temporarily facing a liquidity crisis from an asset-liability mismatch, banking crisis come about also because of insolvency (loan losses exceeding bank capital) resulting from bad (or mispriced) loans, speculation, and even fraud on the part of banks. Insolvencies can either be allowed to run their course, leading to bankruptcies and loss of shareholder value and creditor loans, or the government can bail out its banks. Bailouts could be ominous and shift bank losses to the taxpayers, workers, pensioners and the poor." 21

\section{The Principle of 'Non-Principals'}

This principle requires that any addition to the principal amount that is not exposed to risk-taking must not be protected. Once a capital owner has earned a return having exposed his capital to risk, that should be the end of the deal. If an investor wants to earn continuing returns, he must also share in risk. The two principles: (a) as a matter of principle, capital must earn a return in order for the economic growth to be sustainable and (b) as a matter of principle also, the capital owner must participate in risk to which the capital is applied as part and parcel of everyday business. Insisting on the first principle and disregarding the second is unjust and are at the core of

\footnotetext{
${ }^{21}$ Askari, Hossein, et. al.(2012).
} 
generating economic instability. Note here that current world practice is to exact a reward (agreed interest charge) without the capital provider taking part in the risk of the venture.

If the purpose is to establish justice, principals and non-principals must be treated differently. It is not only the careless or carefree debtor alone who is to be blamed, the insatiable reckless creditor must also share part of the blame and the results: without risk-shared contracting, creditor gets scot-free from his erroneous lending. NonPrincipals need not be guaranteed. Economics tells us that and history gives us that lesson. One of the prominent writers in Islamic finance, Umer Chapra, comments on the verses quoted above as follows: "The principal reason why the Qura'n has delivered such a harsh verdict against interest is that Islam wishes to establish an economic system where all forms of exploitation are eliminated, and particularly, the injustice perpetuated in form of the financier being assured of a positive return without doing any work nor sharing in the risk, while the entrepreneur, in spite of management and hard work, is not assured of such a positive return. Islam wishes to establish justice between the financier and the entrepreneur". ${ }^{22}$ Again note that exacting interest (reward) without partaking in the risk makes lending a risk-less action, which is made worse by government's largesse to take over lender's liability using taxpayers' money.

In this respect, we may draw attention to several research studies that have shown that risk-sharing contracts are superior to interest-based contracts. One such study by Hossein Askari, et al. ${ }^{23}$ makes a convincing case for risk sharing contracts as opposed to no-risk-shared but interest-based contracts. Analysing several studies on the causes of financial crises, they opine that "debt is at the core of all these banking and financial crises". They also point out the reasons why in practice interest-based contracts have dominated the global financial markets. Referring to the MMT that states that in the absence of frictions (e.g., taxation, information asymmetry, transaction costs), a firm's financial structure would be indifferent between debt and equity, they point out that "in the real world there are a number of frictions that bias

\footnotetext{
${ }^{22}$ Chapra, M. Umer (1985), p.64.

${ }^{23}$ Askari, Hossein, et.al. op.cit.
} 
financial structures in favour of debt and debt-based contracts, with the two most important factor being tax and information. The tax treatment of equity returns and interest in industrial countries is heavily biased against equities. Informational issues (information asymmetry and the subsidies and policies that encourage moral hazard and adverse selection) are conceived in favour of debt and debt-based contracts. Broadly speaking, legal-financial systems in advanced countries are structured to favour of debt and debt-based transactions". ${ }^{24}$

Another recent study ${ }^{25}$ concludes that: "Policies that subsidize debt and indirectly penalize equity through taxes and implicit guarantees are distortive. Any desirable public subsidies to banks' activities should be given directly and not in ways that encourage leverage. And while debt's informational insensitivity may provide valuable liquidity, increased capital (and reduced leverage) can enhance this benefit. Finally, suggestions that high leverage serves a necessary disciplining role are based on inadequate theory lacking empirical support. We conclude that bank equity is not socially expensive, and that high leverage is not necessary for banks to perform all their socially valuable functions, including lending, deposit taking and issuing moneylike securities. To the contrary, better capitalized banks suffer fewer distortions in lending decisions and would perform better. The fact that banks choose high leverage does not imply that this is socially optimal, and, except for government subsidies and viewed from an ex ante perspective, high leverage may not even be privately optimal for banks."

Even if we assume that debts were incurred with valid justifications, yet there are circumstances when despite genuine efforts on the part of debtor, he is unable to fulfill his obligations. At that point, a third Islamic principal becomes relevant.

\section{The Principle of Relief}

As stated above, debt once incurred must be discharged, except in very exceptional circumstances. This third principle explains the need, rationale and the rules for providing relief to debtors who are in temporary and genuine difficulties. In

\footnotetext{
${ }^{24}$ Ibid. page 57.

${ }^{25}$ Anat R. Admati et al. (2011).
} 
general, creditors' right to get their principals back must be protected, but they cannot go beyond certain limits. An important distinction must also be made between a delinquent debtor and a distressed debtor due to unexpected external factors. The former is a debtor who has enough assets or fairly certain flows of future income or wealth to discharge his debts. Such debtor must be dealt with strictly. Later in the paper, we will mention legal measures to do that. The latter debtor is a debtor who despite his willingness to pay and sincere efforts made to discharge his debt, is not in a position to honour his payment liabilities because of market failures. Such a debtor deserves to be provided relief.

This principle is also well-established in Islamic law. Two Islamic texts are quoted below, one of which has already been quoted but is repeated to draw the attention to this principle:

(a) "And if the debtor is going through a hard time (has no money), then grant him time till it is easy for him to repay, but if you remit it by way of charity, that is better for you if you did but know." [2:280]

(b) "During the time of Prophet (pbuh), the fruits of one Companion's garden got destroyed due to which his debts piled up. Prophet (pbuh) asked the Companions to collect funds to help him pay his debts. They did, but the collection was not enough to pay the debts. Upon that he told the creditors "take this and you do not have any more claim against him." [Sahih Muslim]

Some important points that emerge from the Hadith quoted above need to be noted. These are:

- The right of the creditor to his principal was recognized [Principle of Principals].

- All possible efforts were made to discharge the debt in full. For this purpose, even charity was collected.

- Having done that, when 'available' money was not enough, debt write-off was granted. 
However, it has to be ensured that the Principal of Relief is not misused. In that respect the distinction between a delinquent debtor and a distressed debtor becomes important. The principal applies only to the latter. As for delinquent debtors, Islamic law provides very strict penalties. These include:

- Delinquent debtor can be jailed (given physical punishment by a Judge).

- Delinquent debtors can be stopped from using their assets for buying or selling, gifting, or transferring through any other manner until they pay their debts.

- Delinquent debtors can be declared "Persona non Grata".

- Delinquent debtors can be humiliated and dishonored, e.g., publishing their names in public media.

- A delinquent debtor can be prohibited from moving out of his city. In modern times, his name can be put in the "Exit Control List".

- Creditors will have the first claim over the inheritance of the debtor.

For distressed debtors, Islamic system has many positive action provisions also. These include:

(i) Prohibition of Interest

That the amount of debt cannot be increased, whether it originated from a loan or an exchange transaction, gives the debtor time to put his house in order. Tolerance shown to the distressed debtor by not increasing the amount of debt and extending the period of repayment is good not only for the debtor. It is also good for the creditors and the economy in general. It has both ethical and economic justification. When markets turn down, decline of collateral value triggers downward spiral as creditors try to protect their positions. However, this would make the market self-destructive, transforming a downturn into a crash. Forbearance relieves debtors, giving them better chances for repayment which will go to the advantage of the creditors. Preserving the value of collaterals and preventing market crash will benefit the entire economy and the society. The practice of debt-restructuring with unpaid interest as principal is disallowed under this rule. 
(ii) Reassignment of Debt (Hawalah):

Reassignment is voluntary and is a charitable act where someone undertakes to pay the debts of another person. No fee, compensation or benefit can accrue to the one taking up this responsibility. ${ }^{26}$ In this regard it is stated in Sahih Bukhari that Prophet (pbuh) said, "Procrastination (delay) in paying debts by a wealthy person is injustice. So, if your debt is transferred from your debtor to a rich person, you should agree."

(ii) Share of gharimeen (those in debt) in zakah

As is well-known to all, charity (zakah) is a compulsory levy imposed by God on every Muslim who has a net-worth above a minimum level. Of the five pillars of Islam, charity is the third one. It is an earmarked levy voluntarily given across the world and managed outside the government revenue. Its beneficiaries are fixed who are grouped into eight categories. One of these eight relates to those who have debts that they are unable to pay. In this way, the rich people in the whole society contribute to payment of debts, in case of distress as a charitable act, a voluntary act.

(iii) Given enough available resources, the state is responsible to discharge the debt. Prophet stated (as a head of the state) that:

"I am more rightful than other believers to be the guardian of the believers, so if a Muslim dies while in debt, I am responsible for the repayment of his debt, and whoever leaves wealth (after his death) it will belong to his heirs." (Sahih Bukhari).

It is important to note that state's responsibility to pay citizens' debts depends on availability of enough resources in the public exchequer. The above saying relates to the period when the Islamic state became prosperous. Earlier, it was the individual or the society who were obliged to bear that burden. As mentioned in an earlier Hadith, charity was collected to pay off debts of farmers who met a calamity. When a massive flood wiped off $\$ 4$ billion infrastructure in the Queensland Australia, a tax was

\footnotetext{
${ }^{26}$ This may not be confused with 'money transfer', whereby an institution transfers money from one place to another against a fee. Charging such a fee is permissible.
} 
imposed at about 1 per cent of incomes of citizens as a forced charity for one year in 2013 !

While selective and well-deserved debt write-off is perfectly in line with Islamic principles, the temptation that it provides to unscrupulous debtors is very strong. A debtor can choose to default intentionally if he so desires. Despite legal provisions in most countries that try to prevent that, bankruptcy fraud is rampant and calls for reform are loud and clear. Such fraud may take the form of concealment of assets by the debtors, multiple bankruptcy filings in different legal jurisdictions, intentional inaccuracies in bankruptcy petitions in order to prolong the proceedings to the disadvantage of creditors and similar other acts of camouflaging.

Bailouts such as Fannie Mae and Freddie Mac in 2008 raise the expectations of future bailouts. That would lend support to the too big to fail theory. In this and other similar cases, rescue operations by central banks by reducing interest rates encourage corporations to 'make hey while the sun shines'. They are tempted to delay putting their house in order in time to avoid eventual collapse. The creditors will get deeper in the abyss by advancing further loans to them considering them safe. The financial institutions will take a happy ride on their low-cost debt to leverage even more. That vicious cycle has no bright side to it. It is an established fact that enterprises like Fannie Mae and Freddie Mac expanded substantially their holdings of sub-prime mortgages concealing facts on their balance sheets. Such experiences could be avoided by another principal derived from Islamic teachings.

(iv) The Principle of Transparency

This principle provides safeguards to ensure that the principle of relief is not misused. If the greed of creditors is insatiable, that of debtors is obsessive. 'Debt Handlers' make billions out of this cheating game. It must be ensured that relief is not misused. It requires strict laws to punish unscrupulous debtors, especially those who manipulate evidence to win relief from the courts. Islamic stance in this regard is very strict. In an authentic Hadith, Prophet (pbuh) stated:

"One who cheats, does not belong to the community of Muslims." (Sunan Abu Dawood). 
The cases of corporate cheating to win relief are very frequent. For example, in the case of the Lehman Bankruptcy in September of 2008 were stuffed with fictitious valuations through Hudson Castle, an entity set up to get the bad stuff off Lehman's balance sheet. In 2006, Merrill Lynch used a technique known as a 'total return swap' to hide its riskier than declared $\mathrm{CDOs}^{27}$ through firms like Pyxis. Citigroup used similar arrangements that the Security Exchange Commission later said should have been disclosed to shareholders in the summer of 2007. In all these cases, the CEOs admitted the facts in court proceedings but pleaded making mistakes and being wrong is no crime. The court appointed Examiners have been alleged to have been bribed to help these concealments. The "buy now, pay later (or never)" culture plagues consumer and corporate borrowers alike.

The above four principles deal with post-debt situations. Islamic teachings also provide guidance for pre-debt circumstances. Taking debt is not prohibited in Islam in recognition of the fact that there may be circumstances under which taking debt becomes inevitable. However, three conditions are prescribed:

- Debts have to be non-interest bearing.

- Debtor has a firm intention to repay the debts and strives for that.

- Debts are taken only to the extent that is inevitable.

The last condition gives us the fifth principle with respect to debt taking.

(v) The Principle of Restraint

This principle prescribes that, while taking debt is permissible, may even be desirable in some cases, the reasons of incurring debt and its aftermath must be carefully considered. Exercising restraint is the rule. This is perhaps the most important of the principles with respect to the role of debt derived from Islamic teachings that are presented in this paper. Huge debt has several disadvantages; it

\footnotetext{
${ }^{27}$ CDO stands for 'Collateralized Debt Obligation'. It is a security; backed by a pool of bonds, loans and other assets. It includes different types of debt, often referred to as 'tranches' or 'slices'. Each slice has a different maturity and risk associated with it. The higher the risk, the more the CDO pays.
} 
dishonours; it disables and kills people and worst, it enslaves people. In this respect, it is pertinent to draw attention to books/stories and terminology that has gained currency: Debt is Slavery; ${ }^{28}$ Debt is Virus $;{ }^{29}$ Debt Bondage, Debtor's Prison; Wage Garnishment, etc.

Being in debt limits one's decision-making power. Consider a person William, who has no debts to pay. He is laid off. He has to find a job. His friend Peter is also laid off. Unfortunately, he has a lot of debt to pay. He also has to find a job, but his need for a new job is much more urgent than that of William. He will most likely accept a job that may not fit his career ambitions. Urgency of his debt instalments will force him to accept something that he does not like. William also has to find a job, sure, but he can wait for something to come up that fits his priorities.

If living beyond one's means is bad for an individual, it is equally bad for corporations and for governments. In resorting to debt finance, restraint is the rule for all, individuals, corporations and governments alike, the three economic agents. Easy money leads people to ignore the precautions that one must take even when taking debt is considered to serve some useful purpose or becomes inevitable. One must never forget that once incurred, debt must be discharged, except in very exceptional circumstances mentioned above. When debt reaches crisis proportions, which it invariably does if restraint is not exercised, attempts are made to sell-off debt which creates bubbles. Sooner or later these bubbles burst and the resulting 'burns' wreck not only the debtors but the economy in general.

In the Wealth of Nations, Adam Smith speaking of public debts stated, "When national debts have once been accumulated to a certain degree, there is scarce, I believe, a single instance of their having been fairly and completely paid.". ${ }^{30}$ Though the actions given in the legal measures against delinquent debtor stated above generally do not apply to governments, the six principles given in this paper equally apply to governments as they do to individuals and corporations.

\footnotetext{
${ }^{28}$ Mihalik, Michael (2007).

29 Jaikaran, Jacques S. (1992).

${ }^{30}$ Smith, Adam, (1904).
} 
Reducing budget deficits is the most important issue in elections in the US and European countries including France. Election promises aside, balancing the budget in present situations of these countries is easier said than done. It requires austerity measures that the electorate cannot digest after they have got used to public supports. Dissenting voices are already being heard, because of political expediencies, rather than economic fundamentals. From an economic point of view budget deficits, except in very special cases and for short periods of time, are bad economics. However, as we hinted above, the shackles of debt once on, are not easy to break out from.

Strong lobbies are created as is evident in most Western countries for perpetuating the status quo. American President, and the author of 'United States Bill of Rights', James Madison, once said, "I go on the principle that a public debt is a public curse, and in a Republican Government a greater curse than any other". Today the US national debt stands at $\$ 16.9$ trillion. The Democrats hold Republicans responsible for the massive increase and blame them to be big spenders, but the fact remains that total Federal debt grew by about US \$4.6-trillion under Obama's first term. During the US 2012 elections, the issue of fiscal cliff became a major topic of debate. It was a program of simultaneous increases in tax revenues and across-theboard government spending cuts scheduled to become effective Dec. 31, 2012. The debate went on during the election campaign with Democrats resisting expenditure cuts and Republicans resisting tax increases.

The Congress could not reach an agreement before the November 2012 elections. In January 2013 a compromise was reached and on January 2, when President Barack Obama signed the compromise bill into law. However, the most important matter of debt ceilings to be imposed on the government could not be resolved. Noble Laureate Maurice Allais pointed out that one of the bad features of debt is that it permits postponement of the decision to adjust. ${ }^{31}$ By the time one realizes the severity of the situation, it is already too late: in few years, the debt-service would amount to 40 per cent of revenue, which is a diversion of funds from economically useful public investments.

\footnotetext{
${ }^{31}$ Maurice Allais (1993).
} 
It is commonly known that debt has not grown for economic reasons. A large majority of American citizens, each one of whom shares around US\$53,000 in the national debt, believes that the reason for the huge debt built up was the so-called War on Terror, not the economy. In the light of the above discussion, it is safe to conclude that reasons for high public debt are largely political not economic. Therefore, it will be useful at this point to discuss the role of state and the Islamic view on that.

\subsection{On the Role of State}

The role of state in any society depends on the prevailing philosophy that it follows. The subject has been one of the most controversial issues in economics. Until 1930s, the dominant philosophy was laissez faire, whereby governments were advised not to intervene in the operation of market. It was believed that rational individuals pursuing their self-interests in competitive markets will achieve both private and public interest simultaneously. The invisible hand of market forces would ensure symmetry between public and private interests and the best allocation of resources. Hence there was no need for the government to assume any economic role accept to set the rules of the game according to the requirements of perfect competition. Government intervention could be accepted only to remove market distortions or to offset market failures.

\section{From 'Market Failure' to 'Government Failure':}

In the aftermath of Great Depression this paradigm was challenged by Keynesian economists on the grounds that markets are generally characterized by imperfections and rigidities and hence may not always ensure full employment and the best allocation of resources. Moreover, the market forces left to themselves may not produce the distribution of income desired by the society. Partly due to rising levels of unemployment and income inequalities and also partly as a reaction to Communist philosophy, governments started taking upon themselves the responsibility of supporting the unemployed, the disabled, the old and the very young. The period starting from early 1940s and stretching well into 1970s was in general dominated by big government philanthrophy all over the world. 
A more serious challenge to the laissez faire paradigm came from Marxist economists who argued that the interaction of the institutions of market and the private property perpetuates injustice and exploitation leading to class conflicts. Hence markets were replaced with central planning and private property with public control of the means of production.

The collapse of socialism in the Soviet Union and Eastern Europe around 1990s shifted the balance once again in favor of economic liberalism. This, however, proved to be short lived. The imperfections of the market, the unrest created by wide disparities in the distribution of income and wealth, the pressing concerns for social justice, unethical use of the enormous powers that the market bestows upon the transnational corporations, and non-sustainability of long run economic growth without active monetary and fiscal policies have once again focused the attention of economists and policy makers on the need for some critical role for the state in economic matters.

As a matter of principle, governments should only 'govern'. ${ }^{32}$ They should not do business. Except for exceptional cases, business should be left to individuals and corporations. Because governments are non-profit organizations and use tax payer's money to provide services, they do not pay as much attention as required to costbenefit analysis. There are also issues relating to good governance. There are severe problems in that area also. Three of these are of critical importance.

- Governments do not use money wisely (economically).

- Governments use money to gain political advantages.

- Government officials and politicians may be corrupt.

It is interesting to note that in the Corruption Perceptions Index (CPI), prepared annually by the Transparency International, many Euro Zone countries, particularly those affected by the financial crisis, including Greece and Italy, are doing worse and worse. Many of the lowest-scoring European countries are those

\footnotetext{
${ }^{32}$ That of course includes the area of regulation and supervision.
} 
hardest hit by the financial and debt crises. A recent quantitative study on determinants of public debt documented what is common street knowledge, a positive correlation between corruption and high public borrowings. The study found that, even when the other fundamentals of the economy suggest that the optimal public debt level should be zero, the presence of corruption can cause significant government borrowing. The corruption-public debt interaction generates endogenous periodic equilibria, where debt cycles between high and low values. These debt cycles offer a possible explanation for why it is common for countries to accumulate debt for extended periods of time, only to abruptly carry out reforms designed to reduce government borrowing. ${ }^{33}$ It seems that we have moved from 'market failure' to 'government failure'. Does that imply moving from bad to worse?

The modern concept of a welfare state, whereby the state guarantees certain welfare benefits to individuals has its own drawbacks. Without going into that debate, let us point to the fact that government benefits become addictive and work as a drag on productive involvement of able-bodied work force. Highly progressive taxes needed to fund those benefits kill incentives to productive investments. Political reasons prevent the governments touching white elephants in the area of health care, unemployment benefits etc. Any cut in 'welfare benefits', even if parasitic, is very hard to carry through. Welfare benefits cannot fall, the government can fall instead. I call it "Downward Rigidity of Welfare Benefits".

A classic and most recent example is the on-going protests by workers, police, doctors, judge and even military against the salary cuts agreed as part of the 'austerity measures' against $€ 130$ billion rescue package granted to Greece. The so-called modern states are facing so many problems that a new workfare model as an alternative to the social welfare systems currently in vogue in many advanced countries is being proposed. Other studies for reforming the welfare benefit system are also being discussed in the literature. ${ }^{34}$

\footnotetext{
${ }^{33}$ Maksym Ivanyna, et.al. (2010)

${ }^{34}$ For example, see Bisaillon, Chris, “(1993).
} 
Under the Islamic system, a hierarchal schema for fulfillment of basic needs is designed. Its implementation is overseen by the state. In such a schema, first and foremost it is the individual who is responsible to meet his and his dependents' expenses. The role of state here is to provide individuals with education, skills and employment opportunities. Then the neighborhood is charged with the responsibility of fulfillment of basic needs of households living in a particular area. After that responsibility falls on the society at large.

Figure 1: Public Private Partnership for Welfare

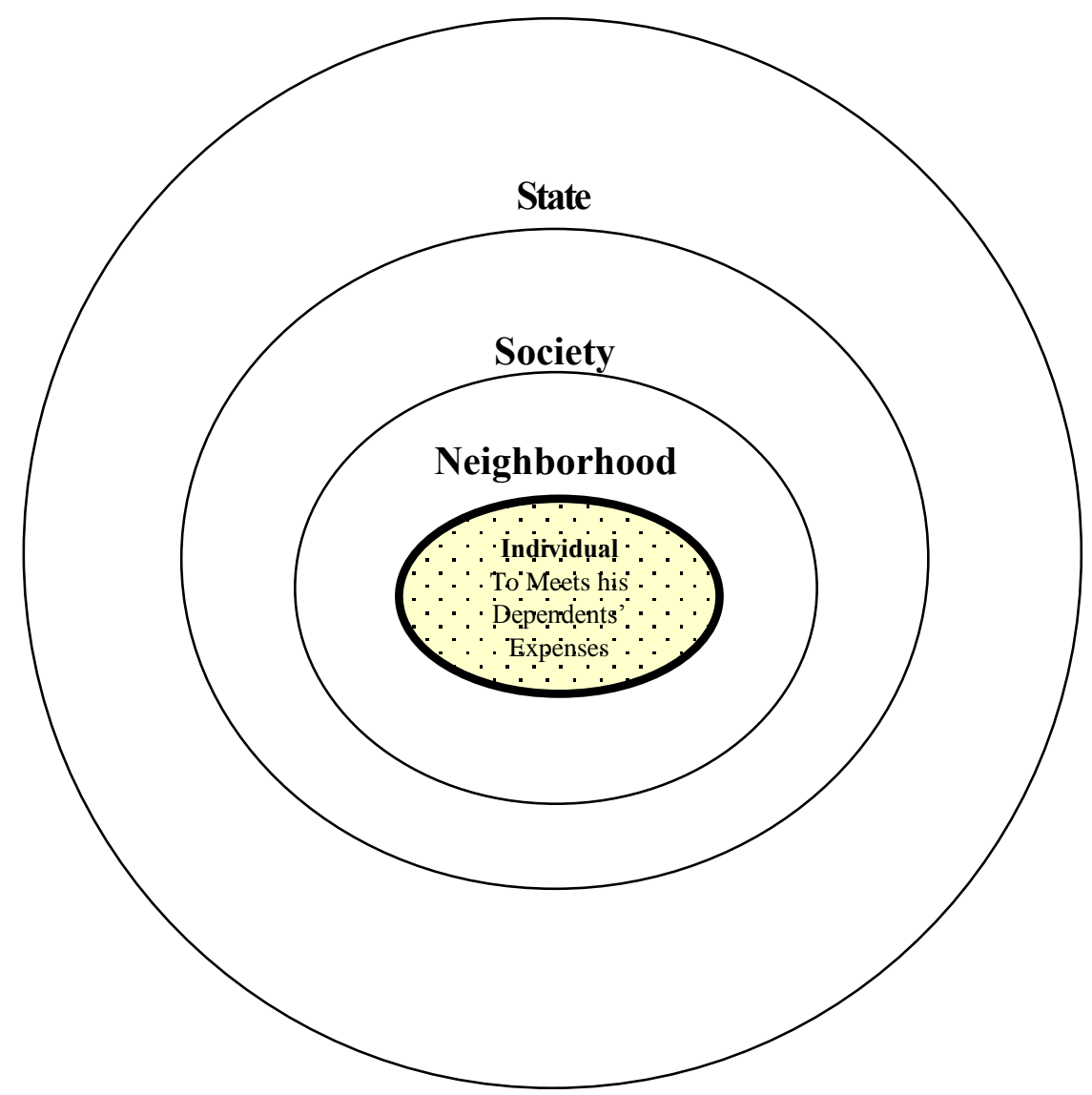

Here Islamic system provides a blueprint for Public Private Partnership for achieving economic welfare goals. Islamic institution of $w a q f^{35}$ which mobilizes resources on non-governmental basis has historically played an important role in

\footnotetext{
${ }^{35}$ Waqf refers to appropriation or tying up a property in perpetuity for specific purposes. No property rights can be exercised over the corpus. Only the usufruct is applied towards the objectives (usually charitable) of the waqf.
} 
achieving social and economic goals of a society. Rich individuals and not-for-profit organizations (NPOs) have been active throughout history from 624 AD to 1924 AD in Islamic countries. Going from below to the top, ultimately, it is the state which guarantees the fulfillment of basic needs. Islamic Schema is presented in Figure 1.

In the area of corporate finance, banks only tell us of their bad debts. What we are trying to argue in this paper is that almost all debt is bad. ${ }^{36}$ If living beyond one's means is bad for an individual, it is equally bad for corporations and governments. In resorting to debt finance, restraint is the rule for all, individuals, corporations and governments alike. Easy money leads people to ignore the precautions that one must take even when taking debt is considered to serve some useful purpose or becomes inevitable. One must never forget that once incurred, debt must be discharged, except in very exceptional circumstances that we will mention under the next Principle. When debt reaches crisis proportions, which it invariably does if restraint is not exercised, attempts are made to sell-off debt which creates bubbles. Sooner or later these bubbles burst and the resulting 'burns' wreck the debtors down to their souls.

Another problem is created by evaluation process used by creditor institutions which, being keen to improve their deployment ratios, ${ }^{37}$ rely more on collateral than on careful project evaluation. Chapra $(2000)^{38}$ correctly argues that: "interest-based lending makes the banks rely on the crutches of the collateral to extend financing for practically any purpose, including speculation. The collateral cannot, however, be a substitute for a more careful evaluation of the project financed. This is because the value of the collateral can itself be impaired by the same factors that diminish the ability of the borrower to repay the loan. The ability of the market to impose the required discipline thus gets impaired and leads to an unhealthy expansion in the overall volume of credit, to excessive leverage, and to living beyond means". Thus the principal of restraint is important for the creditors also.

\footnotetext{
${ }^{36}$ That is not to say that debt has no role whatsoever. The issue has been discussed in detail in section 2.

${ }^{37}$ Deployment ratio is a performance evaluation measure to see how best a bank is using its resources. Its defined as Total Investment/Total Equity + Total Deposits. For details please see Iqbal (2005), p. 76.

38 Chapra, M. Umer, (2000).
} 


\section{The Principle of Monetary-Real Linkage}

IN this section, we expand our discussion on how to link funding to the real economic activities. A principle making debt creation contingent upon linking the monetary to the real sectors of the economy is explained. If there is a grain of truth in the argument that leveraging can be a means to increasing wealth, it must necessarily be qualified. Money creation, whether through borrowing from the central bank by a government (running the printing machine) or through credit creation by commercial banks must be linked to the real sector. The Position Statement of the International Association for Islamic Economics issued at the occasion of Eighth International Conference on Islamic Economics and Finance, held in Doha, Qatar, during December 19-21, 2011, states: "to build a sustainable system, debt must grow in tandem with real (as opposed to financial) wealth; leverage must be capped by productivity potentials. This allows for real wealth to grow without being hurdled with too heavy debt". One of the most prominent Islamic economists, Khurshid Ahmad explains the issue more clearly:

"The delink between money and production activity has led to the emergence of two parallel economies, a money economy and other the real physical economy. Money that was an instrument of exchange and a measure of value became the sole embodiment of value. An instrument that was designed to facilitate exchange and production became an object in itself. Real economy slumbered but financial economy expanded beyond all limits, enriching those alone who were engaged in the business of finance. This created a fiduciary world of its own: money generating more money without producing goods and services in the economy, without increasing the stock and flow of assets in the society. In this new fangled economic order, money became the main player as well as the prize. The process of real value-addition in the economy has been slowed if not disrupted. Money and creation of fiat money became the real game, resulting in the creation of wealth that only produces billionaires without adding much to the well being of the people.

The result is that the delinked system has succeeded in creating an economy wherein presently while the world GDP in current prices is around \$65 trillion, we have an ever expanding realm of fiduciary money, wherein annual trade in derivatives now exceeds $\$ 900$ trillion. In this game the real players and also beneficiaries are only 
a few thousand pseudo-investors while the whole global economy is at the suffering end. The same is true of the foreign exchange markets where daily trade in foreign currencies is fifty times more than the volume of daily movement of trade and tourists. The present day vulnerability and instability of the capitalistic economy owes much to this fatal delink to the real economy."39

\section{Conclusions}

The discussion in the paper pointed out a number of factors that interact to build an economic/financial crisis like the one going on in the EU as well as in several developing and low income countries. Six principles derived from Islamic teachings for debt-taking and debt management have been mentioned as possible long-term solution to recurring debt/economic crises. Now we present our conclusions in the form of Eight Axioms on Debt and Economic Stability inviting other researchers to participate in this dialogue.

Axiom 1. Borrowing/lending on the basis of interest is the root cause of most economic and financial crisis.

Axiom 2. Reward sharing contracts are superior to debt contracts based on interest. [The later dominate in practice largely due to unfair tax treatment of equity].

Axiom 3. Economic instability is a consequence of the delink of money from the real economy, while money is used to fuel speculative transactions including short-selling disconnected to production of credit and production of physical wealth.

Axiom 4. Welfare benefits are downward rigid, a reason for debt addiction.

Axiom 5. Budgetary deficits are largely politically motivated.

Axiom 6. Participation of 'society at large' is necessary for achieving welfare goals. [We call it Private Public Partnership for Welfare (PPPW).]

\footnotetext{
${ }^{39}$ Ahmad, Khurshid (2012).
} 
Axiom 7. Government Failure is as bad as Market Failure and has been a major reason of debt crisis.

Axiom 8. "Too big to fail" theory in the corporate sector has a parallel in the public sector, namely "Too big to manage" and the two are interlinked. [Present day governments (public sectors) are too big. Size of the public sector should be closely linked to public revenue. Balanced budgets as a constitutional requirement with some monitorable flexibility is a good policy option for long term economic stability.]

Author information: Munawar Iqbal $\mathrm{PhD}$ is a professor at the Institute of Islamic Economics, King Abdul Aziz University, Saudi Arabia. He is the founder of the International Association of Islamic Economics in 1974, and has taught and researched on this topic for decades. He lectures and conducts training in Islamic finance throughout the world. The author wishes to record his gratitude to the two editors of the Journal for providing review comments on an earlier version of this paper. Munawar may be contacted at: E-mail: munawariqbal@gmail.com.

\section{References}

Ahmad, Khurshid, (2012). "Global Economic Crisis and the Role of Islamic Economics", IDB Prize Laureate Lecture, April 21, 2012.

Anat R. Admati, Peter M. DeMarzo, Paul Pfleiderer (2011). "Fallacies, Irrelevant Facts, and Myths in the Discussion of Capital Regulation: Why Bank Equity is Not Expensive", Graduate School of Business, Stanford University, Manuscript, March 2011.

Ariff (2012). elgarblog.wordpress.com, October 24.

Ariff, M, Munawar Iqbal and Shamsher Mohamed, eds. (2012). Islamic Debt markets for Sukuk Securities: Theory, Practice and Issues. SKaekwr New York US and Cheltenham, U.K: Edward Elgar Publishing Limited

Ariff, M., John Farrar and Ahmed Khalid eds. (2012). Regulatory Failure and the Global Financial Crisis. SKaekwr New York US and Cheltenham, U.K.: Edward Elgar Publishing Limited.

Askari, Hossein, Zamir Iqbal, Noureddine Krichene and Abbas Mirakhor, (2012). Risk Sharing in Finance: The Islamic Finance Alternative, Singapore: John Wiley and Sons (Asia) Pte. Ltd.

Baum, A, C. Checherita-Westphal and P. Rother (2012). "Debt and Growth: New Evidence for the Euro Area", Working Paper C34 No.1450, Frankfurt: European Central Bank. 
Bisaillon Chris (1993). "Causes and Effects of Welfare Dependency", Illinois Wesleyan University, Honours Project.

Cecchetti,Stephen G, Madhusudan Mohanty and Fabrizio Zampolli (2011). The Real Effects of Debt, Bank of International Settlement, Working Papers No 352, September 2011.

Chapra, M. Umer, (1985). Towards a Just Monetary System, Leicester, UK: The Islamic Foundation.

Chapra, M. Umer, (2000). "International Financial Stability: The Role of Islamic Finance", Policy Perspectives, Vol. 4, No.2, Islamabad: Institute of Policy Studies.

Creditaction.com, Debt Statistics released in April 2013.

Department of Business Information and Skills (2011). "Credit, Debt and Financial Difficulty in Britain (2009/10)", June 2011.

Financial Inclusion Centre (2011) "Report on debt and household incomes".

Friedman, Milton (1957). "The Permanent Income Hypothesis", Chapter 3 in A Theory of the Consumption Function, Princeton: Princeton University Press. Also available at, http://www.nber.org/books/frie57-1.

Henderson Katherine and Grant M. Scobie (2009). Household Debt in New Zealand, New Zealand Treasury Working Paper 09/03.

Iqbal, Munawar and Philip Molyneux (2005) Thirty Years of Islamic Banking: History, Performance and Prospects Houndsmill, UK and New York USA: Palgrave McMillan.

Ivanyna Maksym, Alex Moumouras and Peter Rangazas 2010.

Jaikaran, Jacques S. (1992). The Independent, Friday, April 13, 2012. "Now Euro zone debt virus starts to overwhelm Italy".

Kindleberger, Charles, P., and Robert Z Aliber (2005: fifth edition). Manias, Panics and Crises: A History of Financial Crisis. John Wiley \& Sons, New York, NY, USA.

Kling Michael, http://www.moneynews.com, September, 6, 2013

Leigh Skene (2012). "Repent at Leisure", The Economist, May 24, 2012.

Maurice Allais (1993). The Monetary Conditions of an Economy of Markets: From the Teachings of the Past To the Reforms of Tomorrow, Jeddah: Islamic Research and Training Institute.

Miller, M. H. and Modigliani, F. (1961). Dividend Policy, Growth and the Valuation of Shares. Journal of Business, 34, 411-33.

Modigliani, F. \& Brumberg, R. (1954). Utility analysis and the consumption function: An interpretation of cross-section data. In: Kurihara, K.K (ed.): Post-Keynesian Economics. New Brunswick, NJ: Rutgers University Press.

Nelson Report (2012), Issue No. 989. Available at http://www.nilsonreport.com/

Reinhart, Carmen M. \& Kenneth S. Rogoff (2009), This Time Is Different: Eight Centuries of Financial Folly, Princeton: Princeton University Press.

Smith, Adam, (1904) An Inquiry into the Nature and Causes of the Wealth of Nations, London: Methuen and Co., Ltd., ed. Edwin Cannan, Fifth edition.

Still, Bill, (2011). No More National Debt. Bill-Still Interactive Book. Accessed 15 September, 2013: www.billstill.com.

The Economist. June 16, 2005.

The Financial Times. September, 12, 2013. London, United Kingdom. This article suggested banking reforms as a solution. 
The Independent, Friday, April 13, 2012. "Now Euro zone debt virus starts to overwhelm Italy".

Ursua, J and D. Wilson (2012). "Risks to Growth from Build Ups in Public Debt", Global Economics Weekly, No 12/10, New York: Goldman Sachs

Warner, J. B. 1977. 'Bankruptcy costs: Some evidence' The Journal of Finance, 32(2): 337-348. 